\title{
LATE-GLACIAL STRATIGRAPHY IN ESTONIA
}

\author{
Reet PIRRUS and Anto RAUKAS
}

Geoloogia Instituut (Institute of Geology), Estonia pst. 7, EE-0001 Tallinn, Eesti (Estonia)

Received 4 January 1995, accepted 10 October 1995

\begin{abstract}
The Late-Glacial interval in Estonia starts from the accumulation of Raunis Interstadial deposits in central Latvia about $13500 \mathrm{yr} \mathrm{BP}$ and ends $10000{ }^{14} \mathrm{C}$ years ago. In 1993, a new official stratigraphical chart of Estonian Late-Glacial deposits, described in the paper, was accepted. In the light of the evidence provided by complex investigations, the ice cover started to retreat from the Haanja belt in the Bølling about 13000 years ago. Estonia became free of ice during the second half of the Allerød.
\end{abstract}

Key words: Late-Glacial, stratigraphical chart, marine and continental deposits, stratotypes, stadials and interstadials, pollen assemblage zone, Estonia.

\section{INTRODUCTION}

On 6 May 1993 a new official stratigraphical chart of Estonian LateGlacial deposits was accepted at the session of the Estonian Commission of Stratigraphy (Table 1). A week later it was approved by the 2nd Baltic Stratigraphic Conference in Vilnius (9-14 May). The chart was compiled by the authors of this paper and it is mainly based on the long-term palynological investigations by Reet Pirrus. In Estonia the Late-Glacial deposits above till beds are represented by different clays, silts, and sands comprising plant remains or interlayers, which can be, at least partly, redeposited. This hampers their ${ }^{14} \mathrm{C}$ dating. As those deposits often rest upon the carbonaceous bedrock or limy till, the dating results are significantly affected by the hard water and reservoir effect. Most of the stadials are almost entirely based on lithostratigraphy; biostratigraphical evidence has been considered to a lesser degree.

Marine nearshore sections abound in hiatuses. Pollen grains and spores in these sediments are often repeatedly redeposited. Glacial varved clays have a poor record of the palaeomagnetic field and sedimentological factors produce spurious variations of comparable amplitude to palaeosecular variations. Owing to the above problems the establishment of boundary stratotypes for Late-Glacial sediments is extremely difficult, unit stratotypes, however, will not cover the full time span of chronozones.

Traditionally, the Late-Glacial interval in Estonia starts from the accumulation of Raunis Interstadial deposits in central Latvia (Kaяk et al., 1976) and ends $10000{ }^{14} \mathrm{C}$ years ago. With the decision of the INQUA Congress in Paris (1969) it was acknowledged as the Pleistocene/Holocene boundary. In the Raunis section interstadial sands with alternating layers of silt and clay, containing peat and plant remains, are embedded between two till layers on the right bank of the Raunis River southeast of the town of Cēsis. Organic remains from the Raunis section have been dated in several laboratories (13390 \pm 500 : 
Mo-196; $13250 \pm 160$ : TA-177; $13320 \pm 250$ : Ri-39). The results obtained are in good agreement (Пуннинг et al., 1968b). Nevertheless, recent investigations of Latvian researchers have shown that the layers of the Raunis Interstadial are highly contaminated with younger organic matter and their real age can be much older than hitherto supposed. However, on the other hand, several new intermorainic interstadial sections with rather similar ${ }^{14} \mathrm{C}$ ages recently discovered in Latvia (Raukas et al., 1993, 1995) : Lidumnieku (13 080 \pm 60 : Лy-668A; $12780 \pm 100$ : Jy-668; 12 830 \pm 90 : Лy-695) and Savaini (13 840 0350 : Ri-A-1; $13970 \pm 370$ : Ri-A-2) allow us to place the lower boundary of the Late-Glacial in Estonia at approximately $13500 \mathrm{yr} \mathrm{BP}$ as before.

Table 1

Stratigraphical chart of Estonian Late-Glacial deposits

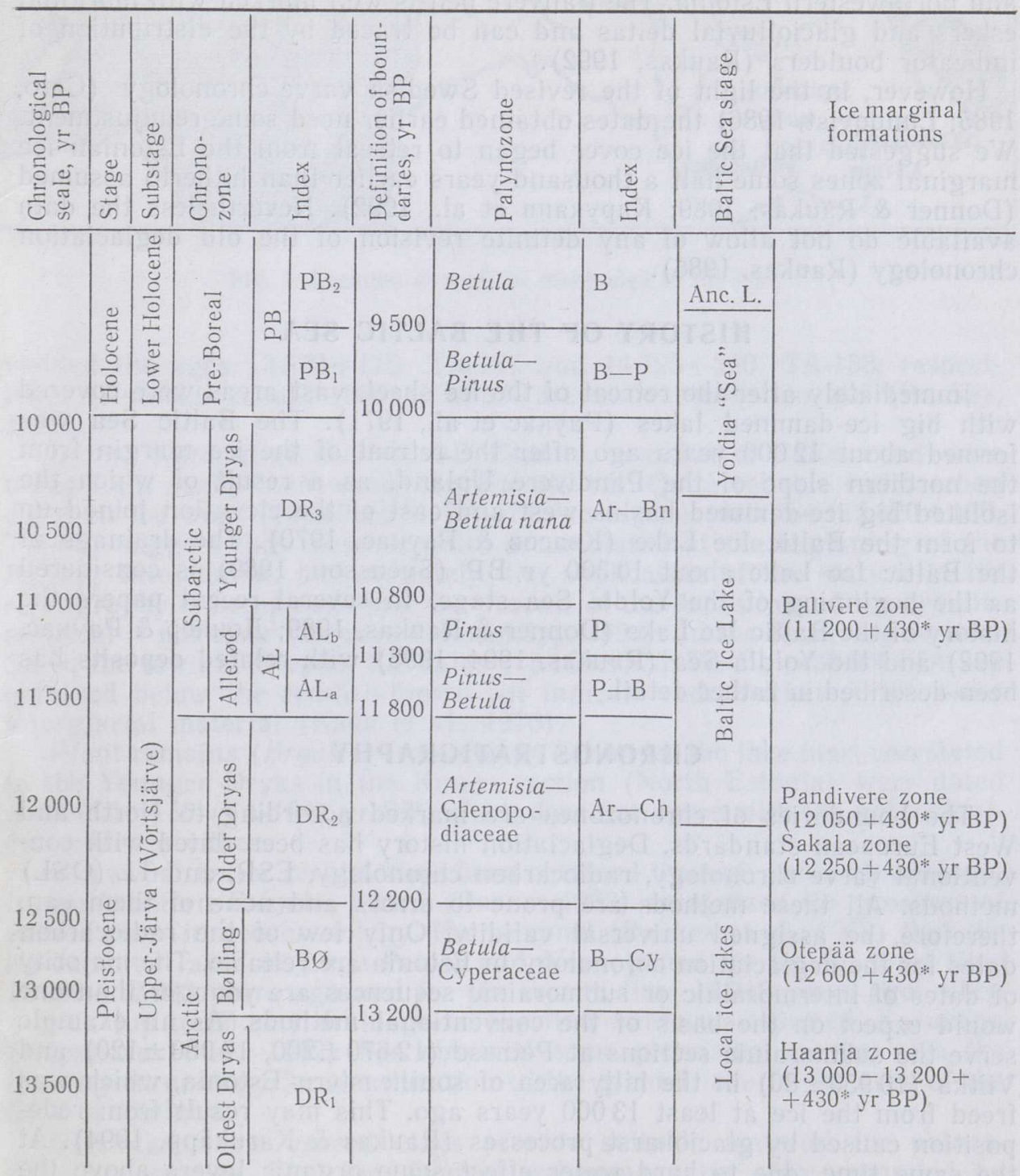

* Swedish varve-chronology correction (Cato, 1985). 


\section{DEGLACIATION HISTORY}

The Estonian territory was freed from the continental ice in the Gotiglacial time about 13500 to 11000 years ago (Raukas, 1986). Against the background of a gradual climatic warming there probably occurred remarkable cooling periods which caused halts or even new advances (Palivere Stadial) of the degrading ice cover marked in the nature by distinct ice marginal formations: Haanja, Otepää, Sakala, Pandivere, and Palivere. It was believed (Raukas et al., 1969) that the ice cover began to retreat from the maximum distribution area of the Haanja belt about $13200-13000$ years ago, from the Otepää-Karula beit about 12600 years ago, from the Sakala belt about 12250 years ago, and from the Pandivere belt about 12050 years ago. According to the traditional approach, the Estonian territory finally cleared of ice about 11000 years ago, but before that the glaciers temporarily reinvaded the West Estonian Archipelago and northwestern Estonia. The Palivere belt is well marked with marginal eskers and glaciofluvial deltas and can be traced by the distribution of indicator boulders (Raukas, 1992).

However, in the light of the revised Swedish varve chronology (Cato, 1985; Lundqvist, 1986) the dates obtained earlier need some readjustment. We suggested that the ice cover began to retreat from the Estonian ice marginal zones some half a thousand years earlier than hitherto assumed (Donner \& Raukas, 1989; Kарукяпп et al., 1992). Nevertheless the data available do not allow of any definite revision of the old deglaciation chronology (Raukas, 1986).

\section{HISTORY OF THE BALTIC SEA}

Immediately after the retreat of the ice sheet, vast areas were covered with big ice-dammed lakes (Payкac et al., 1971). The Baltic Sea was formed about 12000 years ago after the retreat of the ice margin from the northern slope of the Pandivere Upland, as a result of which the isolated big ice-dammed basins west and east of the elevation joined up to form the Baltic Ice Lake (Квасов \& Payкас, 1970). The drainage of the Baltic Ice Lake about 10300 yr BP (Svensson, 1989) is considered as the beginning of the Yoldia Sea stage. In several recent papers the history of the Baltic Ice Lake (Donner \& Raukas, 1989; Доннер \& Раукас, 1992) and the Yoldia Sea (Raukas, 1994, 1995) with related deposits has been described in rather detail.

\section{CHRONOSTRATIGRAPHY}

The boundaries of chronozones are marked according to North and West European standards. Deglaciation history has been dated with conventional varve chronology, radiocarbon chronology, ESR, and TL (OSL) methods. All these methods are prone to errors and none of them can, therefore, be assigned universal validity. Only few of the radiocarbon dates for the deglaciation chronology in Estonia are reliable. The majority of dates of intermorainic or submorainic sequences are younger than one would expect on the basis of the conventional methods. As an example serve the submorainic sections at Petruse $(12670 \pm 200,12080 \pm 120)$ and Viitka $(10950 \pm 80)$ in the hilly area of southeastern Estonia, which was freed from the ice at least 13000 years ago. This may result from redeposition caused by glaciokarst processes (Raukas \& Karukäpp, 1994). At the same time, due to hard water effect some organic layers above the uppermost till are dated at $13000-14000$ BP. For instance, in the Loobu section in the northernmost part of Estonia (Fig. 1) two samples have 


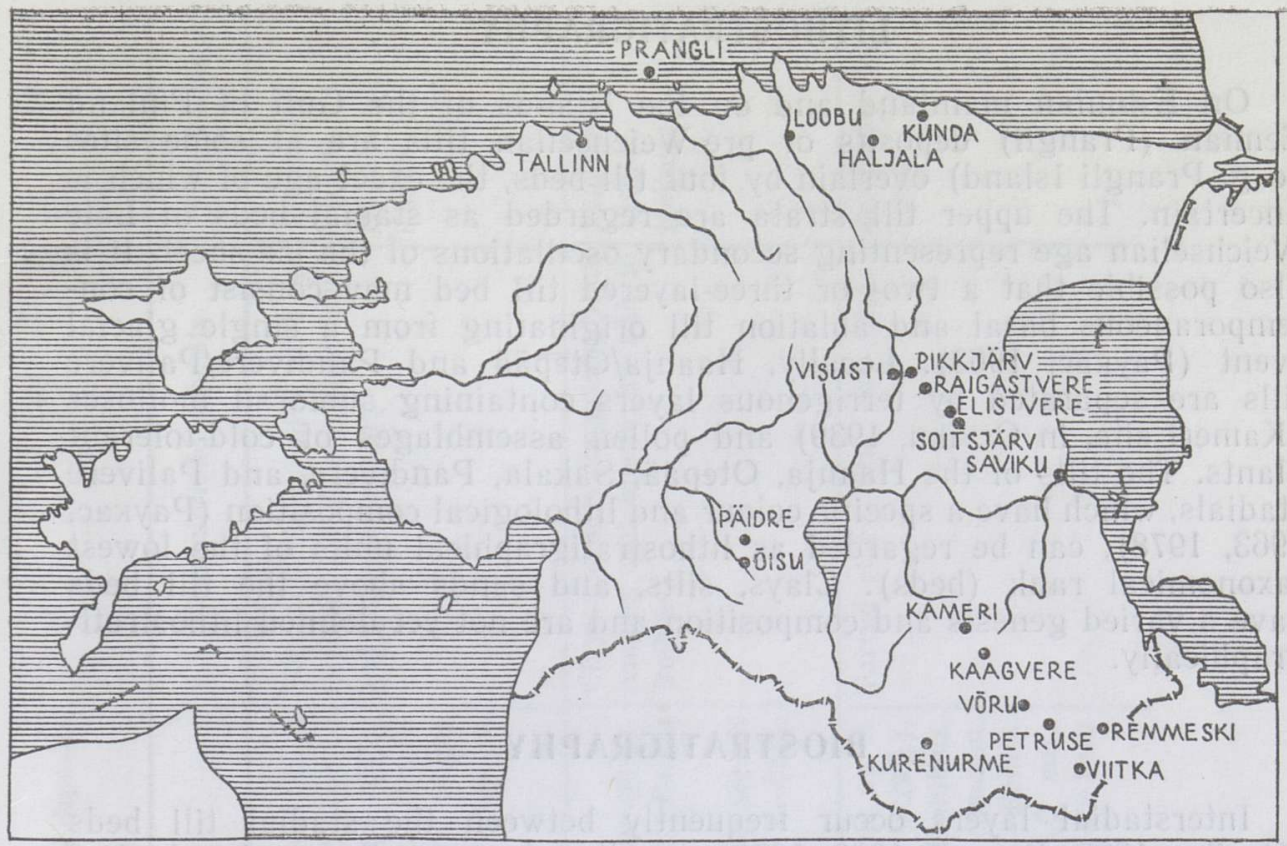

Fig. 1. Location of sections mentioned in the text.

yielded the ages $13970+115$ : TA-137 and $14725+260$ : TA-138, respectively (Пуннинг et al., 1968a), which are undoubtedly too old (Raukas, 1986).

In the Kurenurme section, SE Estonia, remains of Salix wood were taken from sandy loam overlying Haanja till. Quite reliable radiocarbon

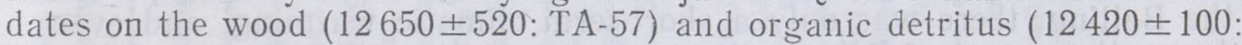
Tln-35) suggest that these deposits accumulated at the beginning of the Bølling Interstadial. Unfortunately, the application of the section in till stratigraphy is hampered since the process of the deposition of the organic material is not clear (Raukas \& Karukäpp, 1994). In the Kaagvere section,

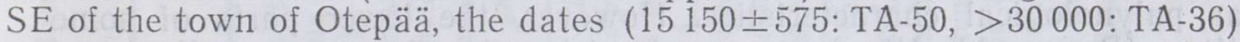
obtained below the reddish-brown till indicate redeposition of the older interglacial material (Каяк et al., 1976).

Plant remains (Bryales) from clayey silt under the lake marl correlated to the Younger Dryas in the Kunda section (North Estonia) were dated at $11690 \pm 150$ (TA-194) yr BP, which does not agree with the palynological evidence either.

Somewhat better results have been obtained through varve chronology. In northeastern Estonia, Rähni (Ряхни, 1963) recognized the prospect of varved clays in geochronology. He assumed (Raukas et al., 1969) that the ice-dammed lakes of Luga-Peipsi and Neva joined up for the first time 12080 - 12083 years ago and for the second time 12049 years ago, when a thick (up to $80 \mathrm{~cm}$ ) drainage or overflow varve was formed. Karukäpp (Карукяпп et al., 1992) has obtained some promising results with the floating chronology for the duration of the glacial lake in the area of the Gulf of Finland.

Glaciolacustrine varved clays provide suitable material for palaeomagnetic studies. The Late-Glacial palaeomagnetic scale compiled by Ekman et al. (Экман et al., 1987) for the Leningrad district and Karelia covers about 6000 years, but unfortunately, its correlation with the palaeomagnetic curves of Estonia is not yet clear (Бахмутов et al., 1987). 


\section{LITHOSTRATIGRAPHY}

On Estonian mainland and on the islands of the Gulf of Finland Eemian (Prangli) deposits or pre-Weichselian tills are at some sites (e. g. Prangli Island) overlain by four till beds, the exact age of which is uncertain. The upper till strata are regarded as stadial beds of Late Weichselian age representing secondary oscillations of the ice sheet. It is also possible that a two- or three-layered till bed may consist of contemporaneous basal and ablation till originating from a single glacial event (Pаукас, 1963). Locally, Haanja/Otepää and Pandivere/Palivere tills are separated by terrigenous layers containing subfossil molluscs (Kameri site, in Orviku, 1939) and pollen assemblages of cold-tolerant plants. The tills of the Haanja, Otepää, Sakala, Pandivere, and Palivere stadials, which have a specific colour and lithological composition (Paykac, $1963,1978)$, can be regarded as lithostratigraphical units of the lowest taxonomical rank (beds). Clays, silts, and sands above the till beds have a varied genesis and composition and are not yet defined lithostratigraphically.

\section{BIOSTRATIGRAPHY}

Interstadial layers occur frequently between the stadial till beds (Orviku, 1939; Paykac, 1963, 1978), but they have no clear palynological characteristics and probably contain a lot of material redeposited from the older interglacials (Liivrand, 1991). For instance, the interstadial deposits of the Prangli section at a depth of 4-15 $\mathrm{m}$ are intercalated between the two uppermost grey tills (Kajak, 1961). They consist of varved glaciolacustrine sediments occasionally containing plant detritus, vivianite, and redeposited pollen grains.

The spore and pollen in Preallerød deposits above the till beds in Estonia suggest severe climatic conditions throughout the Arctic period. In the Bølling, there was only a short-term climatic warming, and even in the southern part of Estonia the environmental conditions were almost glacial with fast accumulation of sediments. Local vegetation just set in to develop and the concentration of redeposited pollen in sediments was high. That is why the Bølling sediments in this region do not reveal any clear palynological characteristics. However, the lower parts of some sections (Remmeski, Võru) are much richer in Cyperacea pollen and poorer in Betula nana L. than the upper parts of the same sections. Occasionally, Ericales pollen and Sphagnum spores are encountered. At the same time, the Bølling sediments in southern Estonia comprise remains of tundra shrubs, and leaves and stalks of Bryales moss which are not found in the lower parts of sections in northern Estonia. Moreover, although there is indirect evidence of the lower parts of sections being Bølling, we have no reliable palynological grounds to state it with conviction, and the lower boundary of the Older Dryas cannot be palynologically defined in our region (Кессел \& Пиррус, 1983). Deposits of Older Dryas age occur both in northern and southern Estonia.

In the light of the pollen evidence, the retreat of the ice margin from the Haanja belt started in the Bølling. The territory of Estonia was finally cleared of the ice in the second half of the Allerød (Пиррус \& Раукас, 1969).

The below-described chronozones and pollen assemblage zones reflect the most important trends in the evolution of Late-Glacial vegetation in Estonia (Table 2). The palynologically described sections, which serve as a basis for the stratigraphical subdivision and stratigraphical chart, are as follows (Figs. 1-3): 
$\frac{a}{2}$

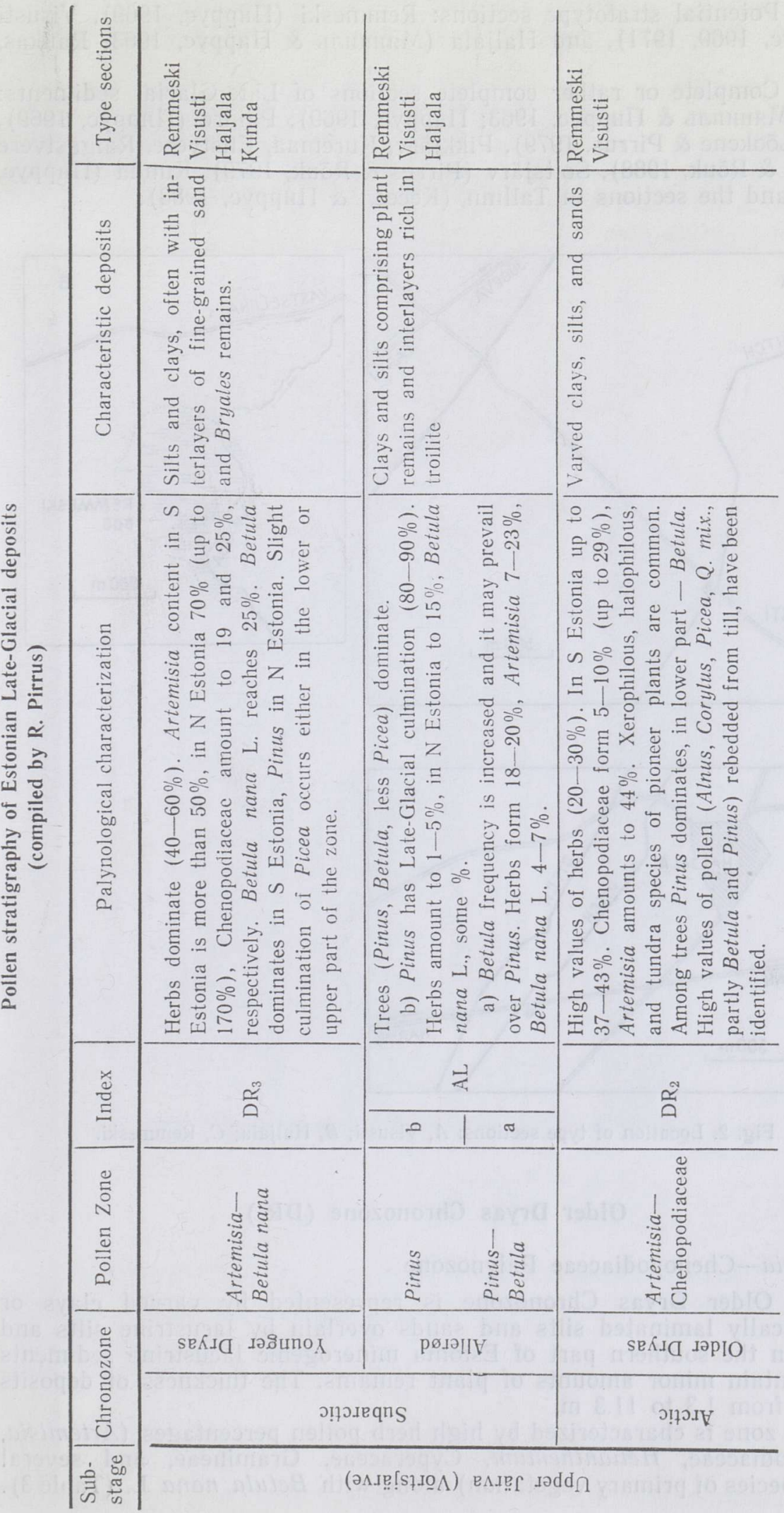


(a) Potential stratotype sections: Remmeski (Пнрpyc, 1969), Visusti (Пиррус, 1969, 1971), and Haljala (Мянниль \& Пиррус, 1963; Raukas, 1986).

(b) Complete or rather complete sections of Late-Glacial sediments: Võru (Мянниль \& Пиррус, 1963; Пиррус, 1969), Päidre (Пиррус, 1969), Oisu (Lõokene \& Pirrus, 1979), Pikkjärv, Kuremaa, Elistvere, Raigastvere (Pirrus \& Rõuk, 1988), Soitsjärv (Pirrus \& Rõuk, 1979), Kunda (Пиррус, 1976), and the sections in Tallinn (Кессел \& Пиррус, 1983).
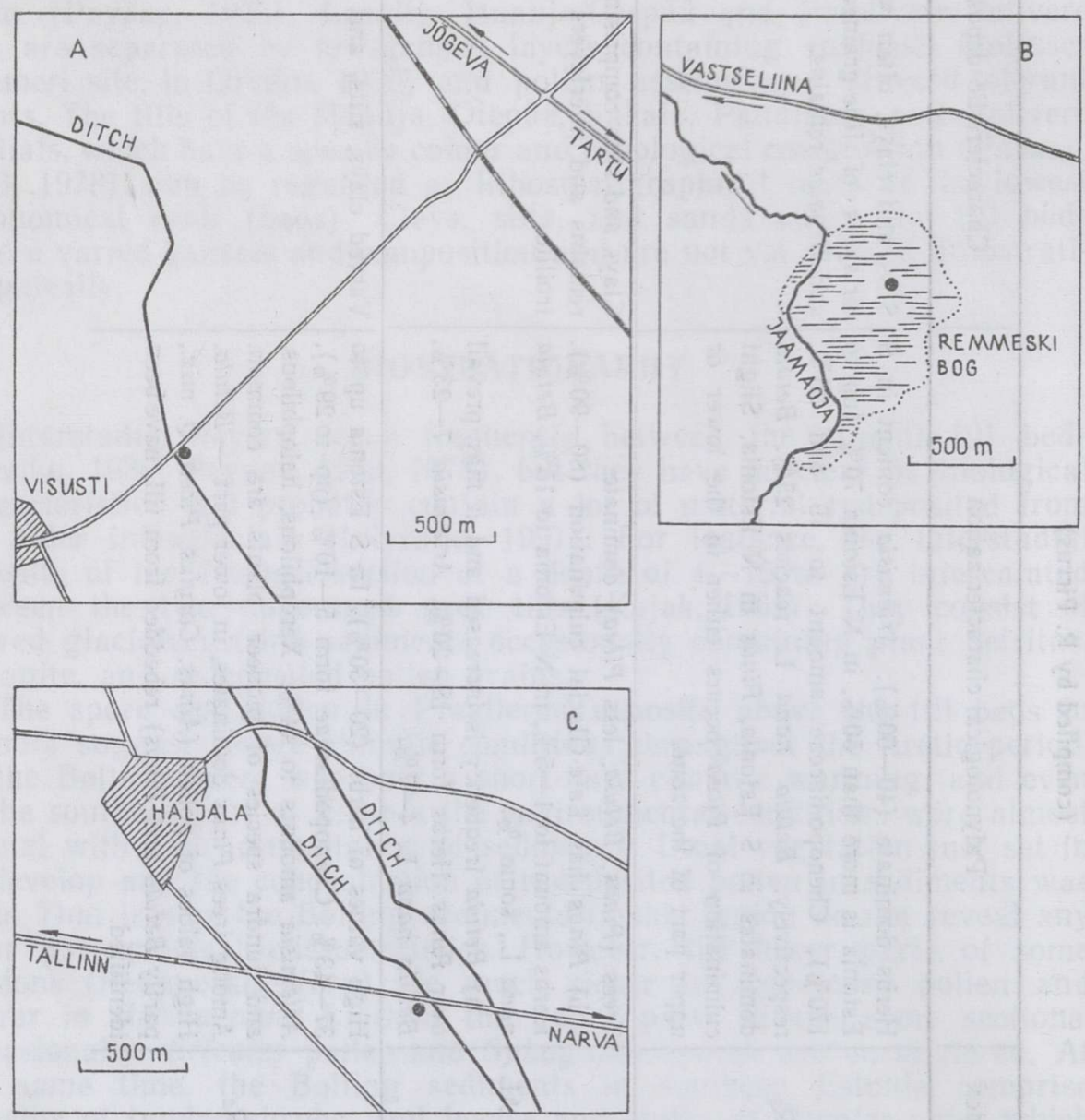

Fig. 2. Location of type sections: $A$, Visusti; $B$, Haljala; $C$, Remmeski.

\section{Older Dryas Chronozone $\left(\mathrm{DR}_{2}\right)$}

\section{Artemisia-Chenopodiaceae Palynozone}

The Older Dryas Chronozone is represented by varved clays or rhythmically laminated silts and sands overlain by lacustrine silts and clays. In the southern part of Estonia minerogenic lacustrine sediments may contain minor amounts of plant remains. The thickness of deposits ranges from 1.3 to $11.3 \mathrm{~m}$.

This zone is characterized by high herb pollen percentages (Artemisia, Chenopodiaceae, Helianthemum, Cyperaceae, Gramineae, and several other species of primary vegetation) along with Betula nana L. (Table 3). 


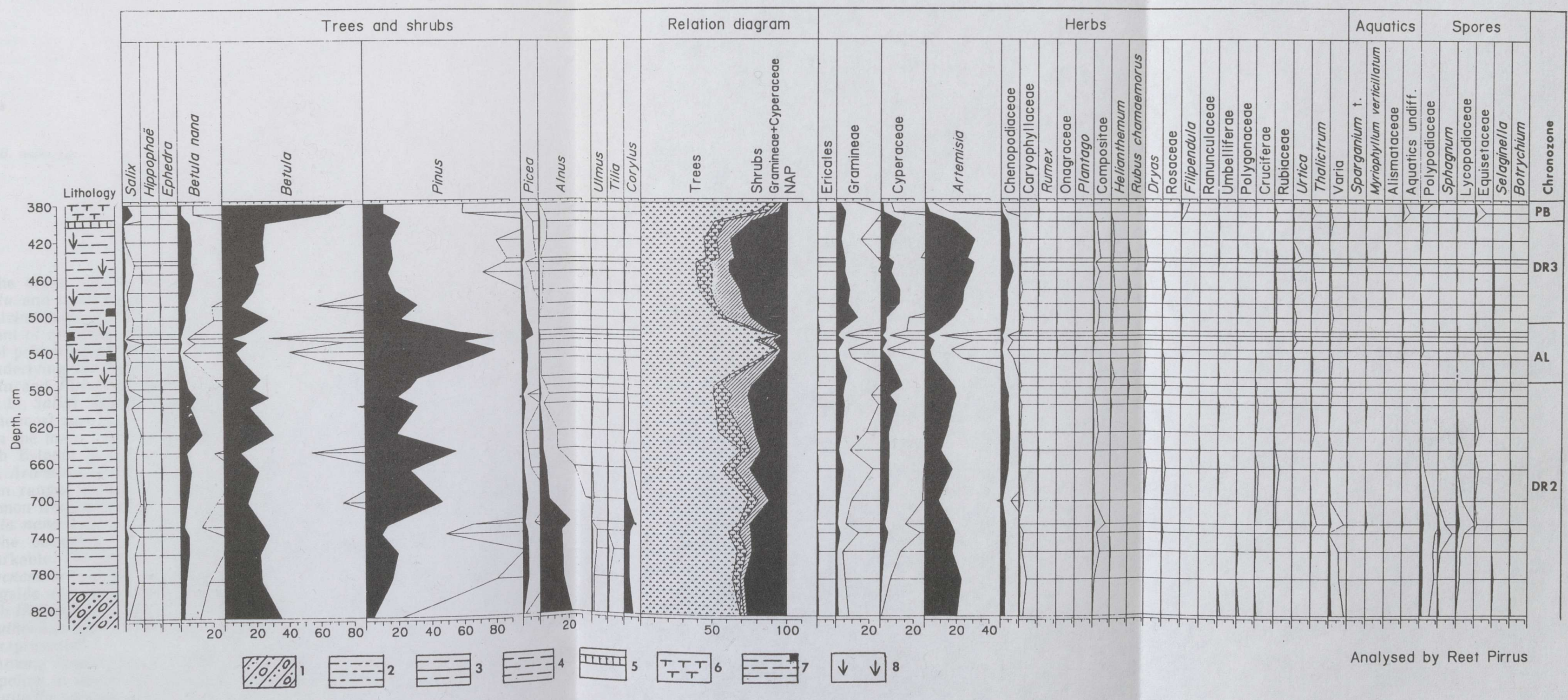

Fig. 3. Pollen diagram of the Visusti section. 1, till; 2, silty sand; 3, rhythmically laminated clayey silt; 4, clayey silt and silty clay with rare fine-grained sand interlayers; 5 , gyttja; 6 , lacustrine lime; 
The content of pollen in the lower and upper parts of the Artemisia-Chenopodiacea Palynozone, \%

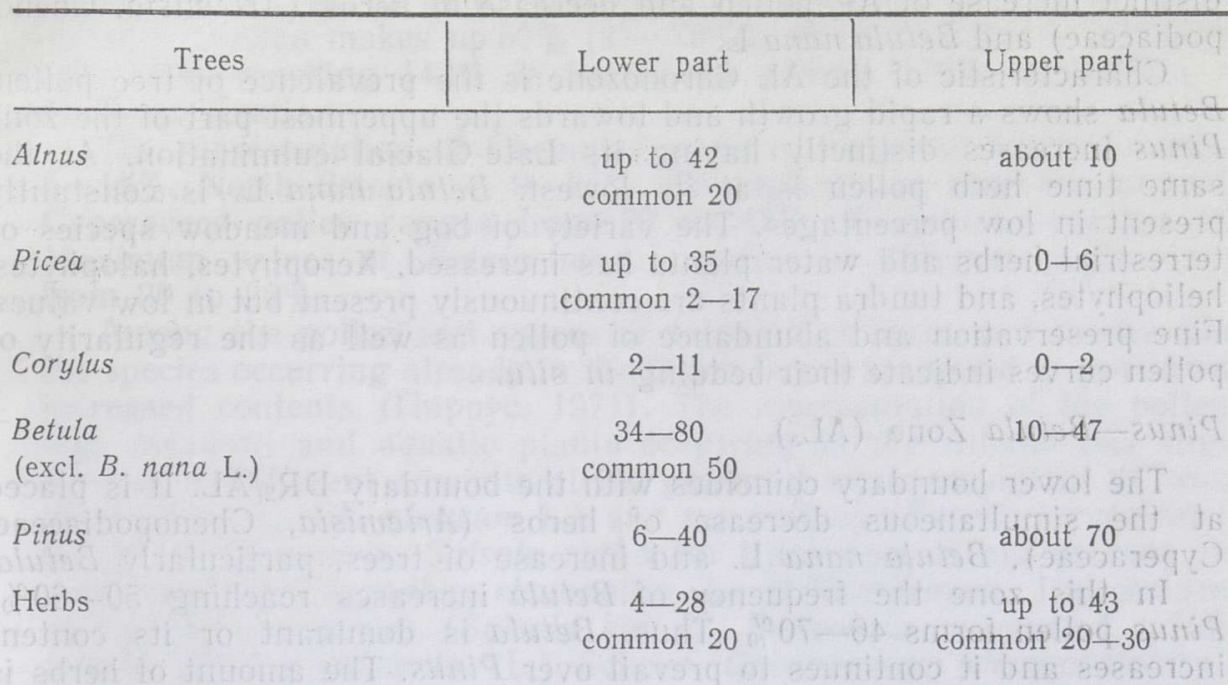

The lower part of the palynozone contains both spores and pollen in situ and those rebedded from till with clayey-silty fraction. In glaciolacustrine sediments the latter ones often prevail. In lake sediments the amount of rebedded pollen is considerably lower or insignificant and pollen of primary rare pioneer vegetation dominates. The pollen composition of underlying till suggests that Alnus, Corylus, Q. mixtum, Picea, partly Betula and Pinus are redeposited. In all probability herbs, shrubs (Betula nana L., Salix), spores of Bryales, tundra species of Lycopodium et al. are for the most part bedded in situ.

In the main part of the zone herb pollen ranges from 20 to $30 \%$. In South Estonia it reaches 37-43\%, in North Estonia (Loobu, Haljala) $29 \%$. Artemisia dominates (up to $44 \%$, generally c. $30 \%$ ). Chenopodiaceae pollen ranges from 5 to $10 \%$ (up to $29 \%$ ), Cyperacea forms $10-20 \%$. Common frequency of $\mathrm{Gramineae}$ does not exceed $5 \%$. The percentage of Betula nana L. is usually high $(10 \%, \max .29 \%)$.

The occurrence of xerophilous and halophilous species pollen is remarkable. The pollen of xerophytes, e. g. Eurotia ceratoides (L.) C.A.M., Polycnemum sp., Chenopodium glaucum L., Ch. botrys L., is present alongside with the pollen of Artemisia, Ephedra, and the mesoxerophilous shrub Hippophae rhamnoides L. Of halophytes Salsola kali L., S. foliosa L., S. ruthenica Iljin, Salicornia europaea L., Kochia prostrata (L.) Schrad are represented.

Among tundra species Betula nana L. has a high percentage. Besides, the pollen of Dryas octopetala L., Rubus chamaemorus L., and spores of Selaginella selaginoides (L.) Link, Botrychium boreale (Fr.) Milde have also been found. In the constituent of trees the pollen of Pinus dominates over Betula.

\section{Allerød Chronozone (AL)}

The Allerød Chronozone is represented by lacustrine clays and silts with blackish-grey interlayers. Scattered plant remains, mostly leaves and stalks of Bryales moss, are common. The thickness of sediments is 0.15 $1.85 \mathrm{~m}$. 
The Allerød Chronozone is subdivided into two parts: (a) PinusBetula Zone $\left(\mathrm{AL}_{\mathrm{a}}\right)$, (b) Pinus Zone $\left(\mathrm{AL}_{\mathrm{b}}\right)$.

The lower boundary of the AL Chronozone is fixed with a rather distinct increase of AP pollen and decrease of herbs (Artemisia, Chenopodiaceae) and Betula nana L.

Characteristic of the AL Chronozone is the prevalence of tree pollen. Betula shows a rapid growth and towards the uppermost part of the zone Pinus increases distinctly having its Late-Glacial culmination. At the same time herb pollen is at its lowest. Betula nana L. is constantly present in low percentages. The variety of bog and meadow species of terrestrial herbs and water plants has increased. Xerophytes, halophytes, heliophytes, and tundra plants are continuously present but in low values. Fine preservation and abundance of pollen as well as the regularity of pollen curves indicate their bedding in situ.

\section{Pinus-Betula Zone $\left(\mathrm{AL}_{\mathrm{a}}\right)$}

The lower boundary coincides with the boundary $\mathrm{DR}_{2} / \mathrm{AL}$. It is placed at the simultaneous decrease of herbs (Artemisia, Chenopodiaceae, Cyperaceae), Betula nana L. and increase of trees, particularly Betula.

In this zone the frequency of Betula increases reaching $50-60 \%$, Pinus pollen forms $46-70 \%$. Thus, Betula is dominant or its content increases and it continues to prevail over Pinus. The amount of herbs is relatively low $(18-20 \%)$. Artemisia pollen ranges from 7 to $23 \%$, Chenopodiaceae make up about $5 \%$, and Betula nana L. $4-7 \%$.

Occasional grains of Filipendula ulmaria L., Valeriana officinalis L., Myriophyllum sp. are found. The frequency of Equisetum spore is usually regular.

\section{Pinus Zone $\left(\mathrm{AL}_{\mathrm{b}}\right)$}

The boundary $A_{b} / A L_{b}$ is fixed with a distinct increase of Pinus and continuous decrease of herbs and Betula nana L. In this zone Pinus has its expressive maximum. The pollen content of Pinus reaches $80-91 \%$, corresponding to the decrease of Betula. Picea is constantly present in low values: Remmeski $2-6 \%$, Võru $1-4 \%$, Visusti $4-9 \%$, Loobu $5-7 \%$, Haljala $4-15 \%$. The herb pollen frequency is usually $1-3 \%$, but in some profiles it reaches $15 \%$. Betula nana L. pollen percentage is low. Artemisia pollen forms commonly $1-8 \%$, Chenopodiaceae $1-3 \%$, Hippophae rhamnoides L., Helianthemum sp., Eurotia ceratoides (L.) C.A.M., Salsola kali L., Ephedra sp., and various halophytes are present sporadically.

The variety of species of mesophilous bog and meadow terrestrial herbs is remarkable: Valeriana officinalis L., Menyanthes trifoliata L., Polygonum persicaria L., P. hydropiper L., Filipendula ulmaria L., Geum rivale L., Epilobium sp., Plantago sp. Water plants are represented by mesophilous species: Myriophyllum verticillatum L., M. celterniflorum L., Sparganium sp., Alisma sp., Nuphar sp., a.o. Equisetum spores are found regularly. Selaginella selaginoides (L.) Link is rare. Finds of Lycopodium species (Lycopodium clavatum L., L. complanatum, Huperzia selago (L.) Bernh. ex Schrank et. Mart.) are occasional.

\section{Younger Dryas Chronozone $\left(\mathrm{DR}_{3}\right)$}

\section{Artemisia-Betula nana Zone}

The Younger Dryas Chronozone is represented by lacustrine silts and clays, often containing fine-grained sand interlayers. Bryales remains are scattered or occur as thin layers, occasionally abounding in hydrotroilite. The thickness of deposits ranges from 0.2 to $4.0 \mathrm{~m}$. 
The zone boundary $\mathrm{AL}_{\mathrm{b}} / \mathrm{DR}_{3}$ is placed at the strong and rapid increase of the content of herb pollen (particularly Artemisia) and Betula nana L. This zone is characterized by remarkably high frequency of herb pollen ranging from 40 to $60 \%$. Artemisia is dominant. In South Estonia Artemisia pollen makes up 50\% (27-78\%), in North Estonia it is usually over $70 \%$, reaching $142 \%$ in the Loobu section, $170 \%$ at Haljala, and $135 \%$ at Kunda.

The representation of Chenopodiaceae is frequent: South Estonia $6-19 \%$, North Estonia - 9-25\%. Throughout the zone the amount of Cyperaceae pollen ranges from 30 to $45 \%$, Gramineae reaches $20 \%$. Maximum values of Betula nana $\mathrm{L}$. pollen in different profiles range from 20 to $25 \%$.

Among the pollen and spores of xerophilous herbs and tundra plants the species occurring already in the Older Dryas are found in considerably increased contents (Пиррус, 1971). The representation of the pollen of bog, meadow, and aquatic plants occurring in the Allerød has slightly decreased. Different amounts of the pollen of mesoxerophilous (Chenopodium album L., Ch. glaucum L.) and xerophilous (Eurotia ceratoides (L.) C.A.M., Polycnemum, Salsola ruthenica Iljin) species are present along with Ephedra, Hippophae rhamnoides L., Helianthemum. The occurrence of halophilous species (Salsola kali L., Salicornia europaea L., Salsola foliosa, Kochia prostrata (L.) Schrad, Chenopodium chenopodioides L.) is common. The representation of the pollen and spores of tundra plants (Dryas octopetala L., Selaginella selaginoides (L.) Link, Ledum palustre L., Rubus chamaemorus L., Botrychium boreale (Fr.) Milde, Lycopodium pungens La Pyl., Lyc. alpinum L.) may be frequent. Among the trees Betula dominates in South Estonia and Pinus in North Estonia. Rather high and regular frequency of Picea can be established in the sections: Kunda - up to $26 \%$, Loobu - up to $20 \%$, and Remmeski $-26 \%$. The Late-Glacial culmination of Picea is either in the lowermost (Võru, Visusti, Haljala) or the uppermost (Remmeski, Loobu) part of the pollen zone.

The accumulation of organic sediments in SE Estonian lakes started $10300-10200$ yr BP, replacing the accumulation of sand, silt, and clay, clearly prevailing during the Late-Glacial. The oldest organic sediments are dated in the Saviku section 10200 90 : ТА-328 (Сарв \& Ильвес, $1975)$. The boundary $\mathrm{DR}_{3} / \mathrm{PB}$ is placed at the rapid increase of tree pollen, prevailingly Betula (about $80 \%$, in SE Estonia up to $90 \%$ ) and Pinus (about 20\%). Among birches Betula sect. Albae prevails. The Betula nana content is rather low $(5-10 \%)$.

According to international rules, all stratigraphical charts should be based on the unit and boundary stratotypes. Unfortunately in Estonia stratotype sections have not been officially accepted for the Late-Glacial deposits. The location of most important type sections is shown in Fig. 2.

\section{ACKNOWLEDGEMENTS}

The authors thank Miss H. Pohl for typing the text and Mrs. H. Kukk for linguistic improvements, Mr. P. Pärkma for the drawings. The research described in this publication was made possible in part by grant No. LK8100 from the Joint Fund Program of Estonia.

\section{REFERENCES}

Cato, I. 1985. The definitive connection of the Swedish geochronological time scale with the present, and the new date of the zero year in Döviken, northern Sweden. Boreas, 14, 117-122. 
Donner, J., Raukas, A. 1989. On the geological history of the Baltic Ice Lake. - Proc. Estonian Acad. Sci. Geol, 38, 3, 128-137.

Kajak, K. 1961. Kvaternaarsete setete Prangli saare tugiprofiil. - In: VI Eesti Loodusuurijate päeva ettekannete teesid. Tartu, 20-21.

Liivrand, E. 1991. Biostratigraphy of the Pleistocene Deposits in Estonia and Correlations in the Baltic Region. Stockholm University, Department of Quaternary Research. Report 19. Stockholm.

Lundqvist, J. 1986. Late Weichselian glaciation and deglaciation in Scandinavia. Quaternary Science Reviews, 5, 269-292.

Lõokene, E., Pirrus, R. 1979. Oisu-Mõõnaste ja Päidre järve geoloogia. - In: Raukas, A. (ed.). Eesti NSV saarkõrgustike ja järvenõgude kujunemine. Valgus, Tallinn, $176-181$.

Orviku, K. 1939. Rõngu interglatsiaal - esimene interglatsiaalse vanusega organogeensete setete leid Eestist. - Eesti Loodus, 1, 1-21.

Pirrus, R., Rõuk, A.-M. 1979. Uusi andmeid Soitsjärve nõo geoloogiast. - In: Raukas, A. (ed.). Eesti NSV saarkõrgustike ja järvenõgude kujunemine. Valgus, Tallinn, $118-144$.

Pirrus, R., Rõuk, A.-M. 1988. Inimtegevuse kajastumisest Vooremaa soo- ja järvesetetes. - In: Loodusteaduslikke meetodeid Eesti arheolongias. ENSV TA Ajaloo Inst., Tallinn, 39-53.

Raukas, A. 1986. Deglaciation of the Gulf of Finland and adjoining areas. - Bull. Geol. Soc. Finland, 58, 2, 21-33.

Raukas, A. 1992. Ice marginal formations of the Palivere zone in the eastern Baltic. Sver. Geol. Unders., Ser. Ca 81, 277-284.

Raukas, A. 1994. Yoldia stage - the least clear interval in the Baltic Sea history. Baltica, 8, 5-14.

Raukas, A. 1995. Evolution of the Yoldia Sea in the eastern Baltic. - Quaternary International, 27, 99-102.

Raukas, A., Āboltinš, O., Gaigalas, A. 1993. Main outlines of geology. - In: Raukas, A. (ed.). Pleistocene Stratigraphy, Ice Marginal Formations and Deglaciation of the Baltic States. Excursion guide, June 14-19. Tallinn, 7-18.

Raukas, A., Āboltinš, O., Gaigalas, A. 1995. Current state and new trends in the Quaternary geology of the Baltic States. - Proc. Estonian Acad. Sci. Geol,, 44, 1, $1-14$.

Raukas, A., Karukäpp, R. 1994. Stagnant ice features in the eastern Baltic. - Zeitsch. f. Geomorph. NF, Suppl.-Bd. 95, 119-125.

Raukas, A., Punning, J.-M., Rähni, E. 1969. Millal taandus Eestist mandrijää? - Eesti Loodus, $7,396-401$.

Svensson, N. O. 1989. Late-Weichselian and Holocene Shore Displacement in the Central Baltic, Based on Stratigraphical and Morphological Records from Eastern Småland and Gotland. Sweden. Lund University, LUNDQUA Thesis 25.

Бахмутов В., Загний Г., Карукяпп Р. 1987. Палеомагнетизм и варвометрия ленточных глин Эстонии и Ленинградской области. - In: Геохронология четвертич. ного периода. Москва, 225-229.

Доннер П., Раукас А. 1992. Балтийское ледниковое озеро. - In: Геология Финского залива. АН Эстонии, Таллинн, 262-276.

Қарукяпп Р., Раукас А., Хюваринен Х. 1992. Дегляциация территории. - In: Геология Финского залива. АН Эстонии, Таллинн, 112-136.

Қаяк К., Кессел Х., Лийвранд Э., Пиррус Р., Раукас А., Сарв А. 1976. Местная рабочая стратиграфическая схема четвертичных отложений Эстонии. - In: Стратиграфия четвертичных отложений Прибалтики (к межведомственному стратиграфическому совещанию, Вильнюс, май 1976 г.). Пяргале, Вильнюс, 4-52.

Қвасов Д. Д., Раукас А. В. 1970. О позднеледниковой истории Финского залива. Изв. Всес. геогр. о-ва, 102, 5, 432-438.

Кессел Х. Я., Пиррус Р. О. 1983. Проблемы стратиграфического расчленения позднеледниковых отложений территории Эстонии по палинологическим данным. - 
In: Палинология в геологических исследованиях Прибалтики и Балтийского моря. Зинатне, Рига, 14-17.

Мянниль Р. П., Пиррус Р. О. 1963. Разрезы позднеледниковых отложений у Хальяла и Выру. - Тр. Ин-та геол. АН ЭССР, 12, 95-105.

Пиррус Р. 1969. Стратиграфическое расчлснение позднеледниковых отложений Южной Эстонии по данным спорово-пыльцевого анализа. - Изв. АН ЭССР. Хим. Геол., 18, 2, 181-191.

Пиррус Р. О. 1971. О результатах количественного видового анализа пыльцы и спор при изучении позднеледниковых отложений на примере разреза Визузи (Южная Эстония). - In: Палинологические исследования в Прибалтике. Зкнатне, Рига, 127-133.

Пиррус Р. О. 1976. Новые данные о стратиграфическом расчленении позднеледниковых отложений разреза Кунда (Северная Эстония). - In: Палинология в континентальных и морских геологических исследованиях. Зинатне, Рига, $60-71$.

Пиррус Р. О., Раукас А. В. 1969. О характере и времени освобождения территории Эстонии от ледников последнего оледенения. - In: Вопросы четвертичной геологии, 4. Зинатне, Рига, 47-57.

Пуннинг Я.-М., Лийва А., Ильвес Э. 1968а. Список радиоуглеродных датировок Института зоологии и ботаники Академии наук Эстонской ССР. - Изв. АН ЭССР. Биол., 17, 4, 426-430.

Пуннинг Я.-М. К., Раукас А. В., Серебрянный Л. Р., Стелле В. Я. 1968b. Палеогеографические особенности и абсолютный возраст лужской стадии валдайского оледенения на Русской равнине. - Докл. АН СССР, 178, 4, 916-918.

Раукас А. В. 1963. Литология разновозрастных морен Эстонской ССР. - Тр. Ин-та геол. АН ЭССР, 12, 9-21.

Раукас А. 1978. Плейстоценовые отложения Эстонской ССР. Валгус, Таллинн.

Раукас А. В., Ряхни Э. Э., Мийдел А. М. 1971. Қраевые ледниковые образования Северной Эстонии. Валгус, Таллинн.

Ряхни Э. Э. 1963. Геохронология ленточных глин Северо-Восточной Эстонии. - Тр. Ин-та геол. АН ЭССР, 12, 81-94.

Сарв А., Ильвес Э. 1975. О возрасте голоценовых отложений приустья реки Эмайыги (по материалам изучения разреза Савику). - Изв. АН ЭССР. Хим. Геол., 24, 1, 64-69.

Экман И. М., Загний Г. Ф., Бахмутов В. Г. 1987. Палеомагнитная стратификация осадочных толщ позднего плейстоцена юго-восточной части Балтийского щита. In: Новые данные по геохронологии четвертичного периода. Москва, 218-224.

\title{
EESTI HILISJÄÄAJA SETETE STRATIGRAAFIA
}

\author{
Reet PIRRUS, Anto RAUKAS
}

On esitatud 6. mail 1993 Eesti Stratigraafia Komisjoni poolt kinnitatud hilisjääaja setete stratigraafiline skeem (tab. 1) ja selle palünoloogiline põhjendus (tab. 2).

\section{СТРАТИГРАФИЯ ПОЗДНЕЛЕДНИКОВЫХ ОТЛОЖЕНИИ ЭСТОНии}

\author{
Рээт ПИРРУС, Анто РАУКАС
}

Представлены утвержденная 6 мая 1993 г. на заседании Республиканской стратиграфической комнссии новая стратиграфическая схема позднеледниковых отложений Эстонии и ее палинологическое обоснование. 